\title{
Purinergic Signaling in Epilepsy
}

\author{
François Rassendren ${ }^{1,3,4}$ and Etienne Audinat ${ }^{5,6 *}$ \\ ${ }^{1}$ CNRS, UMR 5203, Institut de Genomique Fonctionnelle,Montpellier, France \\ 2INSERM, U1191, Montpellier, France \\ ${ }^{3}$ Universite de Montpellier, UMR5203, Montpellier, France \\ ${ }^{4}$ Labex ICST, Montpellier, France \\ 5 INSERM, U1128, Paris, France \\ ${ }^{6}$ Laboratory of Neurophysiology and New Microscopies, Paris Descartes University,Paris, France
}

Until recently, analysis of the mechanisms underlying epilepsy was centered on neuron dysfunctions. Accordingly, most of the available pharmacological treatments aim at reducing neuronal excitation or at potentiating neuronal inhibition. These therapeutic options can lead to obvious secondary effects, and, moreover, seizures cannot be controlled by any known medication in one-third of the patients. A purely neurocentric view of brain functions and dysfunctions has been seriously questioned during

the past 2 decades because of the accumulation of experimental data showing the functional importance of reciprocal interactions between glial cells and neurons. In the case of epilepsy, our current knowledge of the human disease and analysis of animal models clearly favor the involvement of astrocytes and microglial cells during the progression of the disease, including at very early stages, opening the way to the identification of new therapeutic targets. Purinergic signaling is a fundamental feature of neuron-glia interactions, and increasing evidence indicates that modifications of this pathway contribute to the functional remodeling of the epileptic brain. This Review discusses the recent experimental results indicating the roles of astrocytic and microglial $\quad \mathrm{P} 2 \mathrm{X}$ and $\mathrm{P} 2 \mathrm{Y}$ receptors in epilepsy.

Key words: ATP; P2X; P2Y; microglia; astrocyte; status epilepticus; seizure

\section{Epilepsy is a condition of the brain characterized} by the unpredictable occurrence of seizures that result from the abnormal synchronization of neuronal networks in the forebrain. Seizures, therefore, correspond to transient disturbances of neuronal brain functions that can lead to motor behavior abnormalities and loss of consciousness, with devastating psychosocial consequences for patients. Roughly 50 million people worldwide suffer from epilepsy (Hesdorffer et al., 2011). Epilepsy can be controlled but cannot be cured by medication, and about one-third of patients are refractory to pharmacological treatments. For decades, analyses of the mechanisms underlying epilepsy as well as therapeutic approaches have been dominated by a neurocentric view seeking to understand dysfunctions of synaptic and intrinsic membrane properties of neurons. However, it is now clear that reciprocal interactions between neurons and glial cells dynamically modulate synaptic transmission and neuronal network excitability through a large number of signaling pathways (Perea et al., 2009; Kettenmann et al., 2011; Araque et al., 2014; Bergles and Richardson, 2015; Maldonado and Angulo, 2015). Accordingly, increasing evidence suggests that neuron-glia interactions are critical actors in determining the pathophysiology of various neurological disorders, including epilepsy (Steinhauser and

\section{SIGNIFICANCE}

Increasing evidence indicatesthat interactions between neurons and glial cells are fundamental components of brain functions and dysfunctions. Epilepsy has long been studied from a neurocentric point of view, but we now know that astrocytes and microglia are recruited at different phases ofthe disease,including at very early stages.Purineric signaling is central in neuron-glia interactions, and purinergic receptors represent promising therapeutic targets. This Review discusses the experimentatesults on the roles of purinergic signaling in epilepsy, with an emphasis on $\mathrm{P} 2 \mathrm{X}$ and $\mathrm{P} 2 \mathrm{Y}$ receptors expressed by astrocytes and microgliabells.

Contract grant sponsor:Fondation pour la Recherche Medicale; Contract grant number: DEQ20140329488; Contract grant sponsor: European Union ERA-NET Neuron BrIE; Contract grant sponsor: Universite Sorbonne Paris Cite RIPPTSA; Contract grant sponsor: Paris School of Neuroscience; Contract grant sponsor: Program Investissementd'Avenir (LabEx Ion Channel Science and Therapeutics);Contract grant sponsor: Agence Nationale de la Recherche Optogating; Contract grant number: ANR-14-CE11-0004-02

*Correspondence to: Etienne Audinat, INSERM U1128,Paris Descartes University, 45 rue des Saints Pères, 75006 Paris, France. E-mail: etienne. audinat@parisdescartes.fr 
Boison, 2012; Devinsky et al., 2013). Therefore, the role of glia in seizures and epileptogenesis has been put forward as a research priority (Baulac and Pitkanen, 2008; Noebels et al., 2012)

Modifications of glial cell phenotypes are important determinants of the inflammatory reaction that contributes to the remodeling of neuronal networks in epilepsy. These modifications are usually regrouped under the generic terms of gliosis, glial activation, or reactive glia. They actually represent a variety of cell behaviors that are disease and context specific, can be graded and reversible, and may not be uniform or homogeneous within a glial cell population for a given disease (Hanisch and Kettenmann, 2007; Ransohoff and Perry, 2009; Pekny et al., 2016). Reactive astrocytes and microglial cells, the resident macrophages of the CNS, have been observed in specimens of human patients with different forms of epilepsy as well as in animal models of the disease (Vezzani et al., 2011; Devinsky et al., 2013; Marchi et al., 2014). Reactive gliosis has been mostly studied in animal models of temporal lobe epilepsy (TLE). In the case of astrocytes this includes up-regulation of GFAP, modification of the astrocyte morphology, alterations in expression, localization and function of connexins, potassium and water channels, impaired gliotransmission, glutamate uptake and functions of the glutamate- and of the adenosine-converting enzymes, glutamine synthetase and adenosine kinase, respectively (Steinhauser et al., 2015). In the case of microglia, seizure-induced reactivity (or activation) includes morphological changes, proliferation, upregulation of potassium channels and of purinergic receptors, upregulation and release of inflammatory mediators, and modification of process motility (Avignone et al., 2008, 2015; Devinsky et al., 2013). Microglial cells probably react very rapidly to seizure initiation, and the first signs of activation (i.e., production of inflammatory mediators and increased number of processes) are readily detected 30-45 minutes after the start of a status epilepticus (SE; De Simoni et al., 2000; Eyo et al., 2014), even though some other changes require several days to occur (Avignone et al., 2008). It is generally assumed that microglia activation initiates the inflammatory reaction and drives the astrocyte activation. However, functional changes in astrocytes can develop much faster (within a few hours) than upregulation of GFAP, for instance (Bedner et al., 2015), and reciprocal interactions between these two cell types are probably important in setting up the determinants of seizure-induced inflammation. Clearly, our knowledge on the actual phenotypic changes of astrocytes and microglia at different steps of the disease is still fragmented, and there is a crucial requirement for longitudinal and combinatorial studies that would better describe the dynamics of glial cell adaptation to the epileptic condition.

Purinergic signaling is one of the key signaling pathways regulating neuron-glia interactions. In addition to its classical role as a transmitter released by neuronal vesicles at specific synapses, ATP is also released by glial cells, which, in addition, express purinergic receptors that sustain key functions of these cells (Butt, 2011; Matute and Cavaliere, 2011; Rodrigues et al., 2015). The roles of adenosine and its receptors in epilepsy have been extensively studied (for review see Boison, 2015). Adenosine has anticonvulsant effects in both in vitro and in vivo models of epilepsy (Huber et al., 2001; Avsar and Empson, 2004; Etherington and Frenguelli, 2004; Vianna et al., 2005). This action is mediated through the activation of A1 receptors that hyperpolarize neurons and decrease the probability of glutamate release at many excitatory synapses, whereas $\mathrm{A} 2$ and $\mathrm{A} 3$ receptors have opposite convulsive effects (Matute and Cavaliere, 2011; Rodrigues et al., 2015). One key function of astrocytes in regulating the anticonvulsant action of adenosine relies on the activity of the astrocytic enzyme ADK. The expression of $A D K$ is upregulated during epilepsy, leading to a deficiency of adenosine concentration and, consequently, of $A 1$ receptor activation (Boison, 2015). In contrast, the roles of $\mathrm{P} 2$ receptors in epilepsy remain more controversial. In the following paragraphs, we review the roles of $\mathrm{P} 2 \mathrm{X}$ and $\mathrm{P} 2 \mathrm{Y}$ receptors expressed by astrocytes and microglia in epilepsy, focusing mostly on TLE.

\section{MECHANISMS OF ATP RELEASE}

Extracellular signaling properties of ATP were identified during the first half of 20th century, yet it took almost 50 years to establish clearly that ATP fulfills almost all criteria defining a neurotransmitter and 20 additional years to elucidate the molecular nature of purinergic receptors (Burnstock, 2006a). Even now, numerous questions with respect to extracellular ATP remain unanswered or controversial, among which are questions pertaining to the mechanisms of ATP release.

Unlike other signaling molecules, ATP can be released in the extracellular space through different mechanisms. In neurons, following the work of Holton (1959), studies using synaptosomes showed that synaptic vesicles contain high concentrations of ATP (White, 1978). Later, corelease of ATP with other neurotransmitters, such as acetylcholine, GABA, or glutamate, was demonstrated (Fields, 2011a). It has been only recently that the nucleotide transporter (VNUT), concentrating ATP into vesicles, was identified, further supporting a classical vesicular release of ATP by neurons that underlies fast synaptic purinergic transmission (Sawada et al., 2008). VNUT is also expressed in nonneuronal cells, in which it is localized in vesicles of the regulatory secretory pathway, underlying the possibility for numerous cell types to release ATP in a calcium-dependent manner (Lazarowski, 2012). Such mechanisms are well described for T lymphocytes or myeloid cells, including microglia (Imura et al., 2013). VNUT is also associated with vesicles of the lysosomal exocytosis pathways. In astrocytes, several studies have demonstrated that vesicular ATP is released by lysosomal exocytosis and sustains the propagation of intercellular calcium waves in vitro (Bowser and Khakh, 2007; Zhang et al., 2007; Hamilton et al., 2008; Oya et al., 2013). 
In addition to these mechanisms of vesicular release, cytosolic ATP can be released through so-called conductive pathways (Lazarowski, 2012). The best characterized pathway is through hemichannel proteins. Hemichannels are hexameric proteins that form a pore through the plasma membrane. Two families of proteins can form hemichannels, the connexins and the pannexins. Although these two families of protein do not share significant amino acid sequence homology, they have similar membrane organization, function, and pharmacology (Orellana and Stehberg, 2014). Unlike gap junction, hemichannels are not involved in cellular coupling but allow direct exchange between the cytoplasmic compartment and the extracellular space. Most connexin and pannexin hemichannels exhibit ATP permeability, although with various efficacy and cell specificity (Lohman and Isakson, 2014). Experimental conditions leading to ATP efflux through connexin pores require low external calcium and strong depolarization that are outside physiological range, suggesting that connexin-evoked ATP release may be related mostly to pathological conditions. Among the three pannexin proteins, pannexin-1 (PANX1) is the best characterized isoform. Many studies have demonstrated that, under physiological conditions, PANX1 can release ATP in response to the activation of different signaling pathways (Bao et al., 2004). Because PANX1 is widely expressed and activated for membrane potential in the physiological range, it has been considered as the major hemichannel allowing cellular ATP efflux. PANX1 activity can be triggered by purinergic receptor activation (Pelegrin and Surprenant, 2006). This positive feedback loop constituted by ATP-induced ATP release may support the role of ATP as a danger signal under pathological conditions (Rodrigues et al., 2015). Although results obtained from connexin- or pannexin-deficient mice are somewhat prone to controversy (Hanstein et al., 2013), data obtained from these mice support the view that these two hemichannel families contribute to the release of ATP into the extracellular space, particularly under pathological conditions.

Other conductive pathways have also been documented. Cellular swelling and mechanical cell deformation lead to a surge in extracellular ATP. Although PANX1 appears to be mechanosensitive (Beckel et al., 2014), ATP release evoked by cell swelling is more likely related to activation of the large-conductance volumeregulated anionic channel (VRAC) and maxianion channels. Although ATP efflux through VRAC is still controversial, there is compelling evidence that maxianion channels contribute to ATP release (Islam et al., 2012). For neurons, these channels have been proposed to be activated by local variations of osmolarity along the axon that occur during action potential propagation (Fields, 2011b), leading to an activity-dependent ATP release from axons. Similarly, based on pharmacological sensitivity to gadolinium, massive ATP release from astrocytes evoked by oxygen-glucose deprivation likely is due to the activity of maxianion channels (Liu et al., 2008).
In conclusion, ATP release involves multiple mechanisms that can be differentially triggered by physiological or pathological stimuli. In the nervous system, extracellular ATP has important functions in neuron-glia communication through the activation of purinergic P2 receptors.

\section{PURINERGIC RECEPTORS}

Extracellular tri- and dinucleotides act on two main classes of membrane receptors, P2Y and P2X receptors, that are G-protein-coupled receptors and ATP-gated channels, respectively (Burnstock, 2006b). In mammals, height $P 2 Y$ receptors are known $(P 2 Y 1, \quad 2,4,6,11,12$, 13 , and 14), although P2Y11 is not present in rat and mouse genomes. They exhibit differential sensitivity to either adenine or uracil nucleotides (von K€ ugelgen and Hoffmann, 2015); most P2Y receptors have a lower affinity for ATP than for other purines such as ADP, UTP, UDP, or UDP-glucose. Pharmacology of P2Y receptors is well defined. There are specific antagonists for all of them except for P2Y2 and P2Y14; however, these two receptors can be activated by specific agonists. All eight $\mathrm{P} 2 \mathrm{Y}$ receptors are expressed in the brain, particularly in glial cells.

There are seven cloned P2X subunits. These subunits can assemble to form homo- or heterotrimeric channels, potentially encoding an important number of receptor complexes. However, only limited numbers of heterotrimeric $\mathrm{P} 2 \mathrm{X}$ receptors have been unambiguously characterized thus far. Unlike P2Y receptors, P2X receptors are activated only by ATP or its derivatives, such abmeATP, ATP-g-S, or BzATP. They are not sensitive to dinucleotides or uracil nucleotides. Only a few specific antagonists for $\mathrm{P} 2 \mathrm{X}$ receptors are available. These molecules target, with high specificity, P2X1, P2X2, P2X3, $\mathrm{P} 2 \mathrm{X} 2 / 3$, or $\mathrm{P} 2 \mathrm{X} 7$ channels. Specific and wellcharacterized antagonists for P2X4 receptors are still lacking, despite some recent improvement (Khakh and North, 2012). P2X5 and P2X6 have received little attention because they are either nonfunctional as a homomeric receptor (P2X6) or inappropriately spliced in humans (P2X5; Collo et al., 1996; Bo et al., 2003).

In the nervous system, all cell types express $\mathrm{P} 2 \mathrm{X}$ receptors, yet each cell type expresses only a subset of subunits. P2X2, P2X3, and P2X6 are found only in neurons, whereas $\mathrm{P} 2 \mathrm{X} 4$ has been characterized in neurons, microglia, and oligodendrocytes. The pattern of expression of P2X7 is more problematic. Although different groups have reported the expression of $\quad$ P2X7 in neurons and astrocytes, these findings, often based on poorly selective pharmacological tools, are still controversial; unambiguous expression of P2X7 has been demonstrated in microglia (Khakh and North, 2012). A subset of cortical astrocytes expresses functional heteromeric P2X1/P2X5 receptors (Lalo et al., 2008). It is important to keep in mind that expression of $\mathrm{P} 2 \mathrm{X}$ receptors is highly dynamic and can dramatically change under pathological conditions. For example, P2X4 is absent from resting microglia 


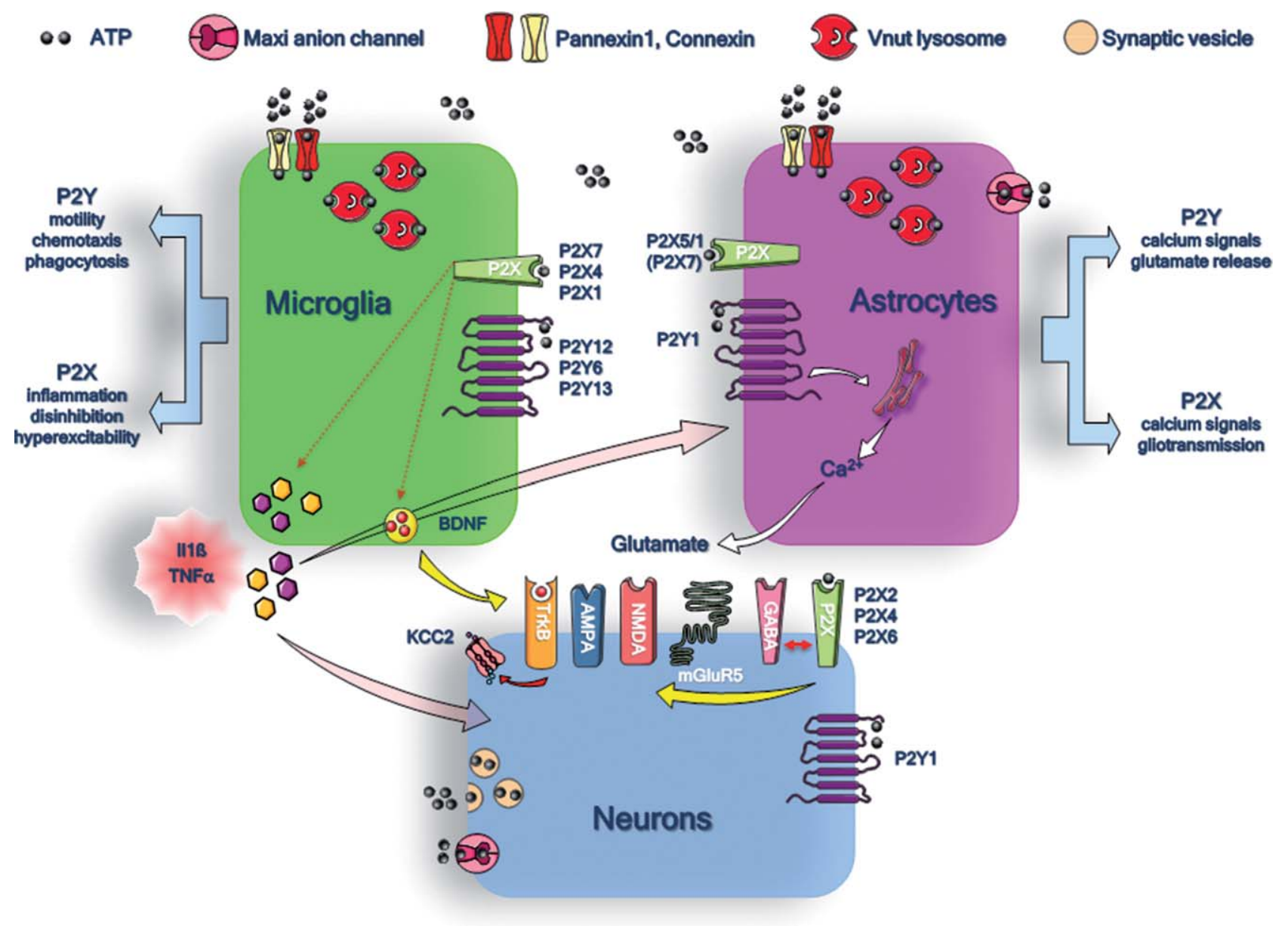

Fig. 1. Purinergic signaling pathways between neurons, astrocytes, and microglial cells. The different release mechanisms ofATP and the expression of $\mathrm{P} 2 \mathrm{X}$ and $\mathrm{P} 2 \mathrm{Y}$ receptors are indicated for microglia (green), astrocytes (violet), and neurons (blue). The involvement of microglial P2X receptors in the production of the IL-1b, TNF-a, and BDNF and that of astrocytic P2Y1 receptors in the release of glutamate are highlighted. The putative functions of glial P2X and P2Y receptors are also indicated at right and at left of the microglial cell and of the astrocyte, respectively.

but is strongly upregulated in activated cells nerve injury or induction of Ulmann et al., 2008, 2013).

\section{PURINERGIC SIGNALING IN THE CNS}

\section{P2X Receptors}

Figure 1 summarizes the main purinergic signaling pathways, and their functions, between neurons, astrocytes, and microglial cells. Just as with other ligand-gated channels, P2X receptors could contribute to fast synaptic transmission. Consistent with this idea, several studies have demonstrated that $\mathrm{P} 2 \mathrm{X}$ receptors can be activated at synapses of different brain regions. However, these excitatory postsynaptic currents are small and rare and occur in few cells within given brain nuclei/areas (Pankratov et al., 2007; Khakh and North, 2012). Our current understanding of P2X signaling in neurons is that these receptors following have neuromodulatory rather than true excitatory properal., 2003; ties. Supporting this view, P2X receptors can alter NMDA-dependent synaptic functions either by regulating the membrane insertion of the GluN2B subunit (Baxter et al., 2011) or by regulating NMDA receptor inactivation (Pankratov et al., 2002). Similarly, a recent study showed that P2X receptor activation triggers AMPA receptor internalization and thus can regulate glutamatergic fast synaptic transmission in the hippocampus (Pougnet et al., 2014). By direct interaction with GABA receptors, $\mathrm{P} 2 \mathrm{X} 4$ receptors can negatively control the generation of inhibitory postsynaptic currents, promoting, although indirectly, network excitability (Jo et al., 2011).

The function of P2X receptors in astrocytes is poorly documented. In the hippocampus, where astrocytes have been studied the most, fast applications of P2X receptor agonists during whole-cell recordings of astrocytes in the mouse, rat, and human CA1 region failed to 
trigger any detectable membrane current that could support the existence of functional $\mathrm{P} 2 \mathrm{X}$ receptors in these cells (Jabs et al., 2007), yet, as stated above, heteromeric P2X1/P2X5 receptors have been functionally characterized in a subset of cortical astrocytes (Lalo et al., 2008); however, the physiological role of this heteromeric receptor remains speculative. It is possible that $\mathrm{P} 2 \mathrm{X} 1 / 5$ activation can contribute to astroglial calcium signaling and may represent a fast neuron-to-glia signaling mechanism at the synaptic level. Alternatively, P2X-evoked sodium influx in astrocytes may interfere with the glutamate buffering capacity of astrocytes.

The expression of $\mathrm{P} 2 \mathrm{X} 7$ in astrocytes is highly controversial. Indeed most studies demonstrating functional P2X7-like receptors in astrocytes in vitro or ex vivo rely on the use of pharmacological tools with little specificity. Moreover, a recent study demonstrated that heteromeric $\mathrm{P} 2 \mathrm{X} 2 / 5$ receptors have pharmacological and functional properties close to those of $\mathrm{P} 2 \mathrm{X} 7$, including activation by micromolar BzATP concentration, pore dilatation characteristics, and induction of pseudoapoptosis, supporting the view that other $\mathrm{P} 2 \mathrm{X}$ receptors present the same hallmark of activation as P2X7 (Compan et al., 2012). Nevertheless, several studies have provided convincing results showing the expression of $\mathrm{P} 2 \mathrm{X} 7$ in radial glial cells, such as Muller glia in the retina (Pannicke et al., 2000) or Bergmann cells in the cerebellum (Habbas et al., 2011). Moreover, it has recently been shown in vivo that the induction of P2X7 expression in activated cortical astrocytes contributes to ischemic tolerance induced by a preconditioning sublethal insult (Hirayama et al., 2015). P2X receptor expression in cultured oligodendrocyte precursor cells has been reported; however, these observations have not been reproduced in mature oligodendrocytes in situ (Matute, 2008). P2X7 is potentially expressed in a subset of oligodendroglia (Domercq et al., 2010), yet these studies suffer from the same limitation as described above.

Expression of P2X receptors in microglia is well documented. Microglial cells are brain-resident macrophages known for their involvement in neuroinflammation (Hanisch and Kettenmann, 2007; Ransohoff and Perry, 2009). Increasing evidence indicates that microglial cells also have numerous homeostatic functions in healthy brain or during development (Kettenmann et al., 2013; Wu et al., 2013; Shemer et al., 2015; Arnoux and Audinat, 2015). Microglia behaviors are shaped by the activity of nearby networks, including neurons and astrocytes under both healthy and pathological conditions (Kettenmann et al., 2013). Microglial cells have long and branched processes that present remarkable and unique motility properties, allowing them to scan their environment and establish transient contact with synapses. These processes can also rapidly extend toward a local lesion, and several studies have demonstrated that purinergic signaling, particularly through the P2Y12 receptor, is a central regulator of microglial process motility (Parkhurst and Gan, 2010). Purinergic receptors shape many other functions of microglial cells, particularly their ability to interact with other brain cell types, and, from this point of view, they share many characteristics with peripheral macrophages, which are known to express both P2X and $\mathrm{P} 2 \mathrm{Y}$ receptors.

In microglia, as in macrophages, the expression of $\mathrm{P} 2 \mathrm{X} 1, \mathrm{P} 2 \mathrm{X} 4$, and $\mathrm{P} 2 \mathrm{X} 7$ receptors is clearly established. $\mathrm{P} 2 \mathrm{X} 7$ receptors, which are highly expressed in all myeloid cells, display unusual biophysical, pharmacological, and functional properties compared with other $\mathrm{P} 2 \mathrm{X}$ receptors (but see Compan et al., 2012); they have a very low sensitivity for ATP (EC50 above $1 \mathrm{mM}$ ), and their activation opens a permeation pathway for high-molecular-weight molecules. The main functional characteristic of P2X7 is its ability to activate the inflammasome, leading to procaspase-1 cleavage and interleukin (IL)-1b processing and release. Mice deficient for the $\mathrm{P} 2 \mathrm{X} 7$ gene are unable to process and secrete mature IL-1b or IL-18 in response to an inflammatory challenge and display a severe alteration of the expression of other proinflammatory cytokines, including tumor necrosis factor-a (TNF-a; Solle et al., 2001). P2X7-deficient mice have normal pain sensation but do not show any hypersensitivity to mechanical stimuli in models of pathological pain (Chessell et al., 2005). This phenotype likely is due to an alteration of microglial proinflammatory functions in the spinal cord. It is surprising that only a few studies have investigated the cellular mechanisms underlying the contribution of microglial $\mathrm{P} 2 \times 7$ receptors in brain pathologies and inflammation. P2X7 receptors are also expressed by microglia under physiological conditions (Avignone et al., 2008), suggesting that these receptors contribute to microglia homeostatic functions.

Unlike P2X7, P2X4 receptors are not expressed in quiescent microglia but are strongly upregulated in activated cells under diverse pathological conditions. After sciatic nerve ligation, a model of neuropathic pain, P2X4 is expressed de novo in activated spinal microglia in which this receptor contributes to a calcium-dependent brain-derived neurotrophic factor (BDNF) release. The latter will, in turn, promote network excitability through downregulation of the chloride-potassium cotransporter KCC2 and GABAergic disinhibition (Beggs et al., 2012). $\mathrm{P} 2 \mathrm{X} 4$ has a strong permeability to calcium, equivalent to that of NMDA receptors (Egan and Khakh, 2004). In myeloid cells, P2X4-evoked calcium entry activates phospholipase A2 and stimulates the production of arachidonic acid and prostaglandin 2, the latter inducing sensitization of sensory neurons (Ulmann et al., 2010). P2X4 is likely to have a similar function in brain microglia, potentially contributing to neuronal excitability within the CNS. Other microglial functions are regulated by P2X4-evoked calcium influx, as suggested by the fact that microglial cells in P2X4-deficient mice show attenuated activation hallmarks in disease models (Ulmann et al., 2008, 2013).

The role of P2X1 in microglia has not been investigated. In macrophage, P2X1-deficient mice have altered neutrophil extravasation and reduced plasma levels of key cytokines and chemokines in an endotoxemia model (Maitre et al., 2015). This phenotype suggests that P2X1 
could also contribute to microglial proinflammatory functions.

\section{P2Y Receptors}

The functions of $\mathrm{P} 2 \mathrm{Y}$ receptors in the CNS are still poorly characterized. As for most other G-proteincoupled receptors, $\mathrm{P} 2 \mathrm{Y}$ receptors in neurons appear to have neuromodulatory functions, yet there is only sparse evidence that $\mathrm{P} 2 \mathrm{Y}$ receptors endorse important neuronal functions (but see Bowser and Khakh, 2004). By contrast, $\mathrm{P} 2 \mathrm{Y}$ receptors are major determinants of glial cell activity. Astrocytes are thought to express several types of P2Y1, $\mathrm{P} 2 \mathrm{Y} 2$, and $\mathrm{P} 2 \mathrm{Y} 4$ receptors in situ (Verkhratsky et al., 2009), among which P2Y1 has been the most extensively studied. Activation of P2Y1 triggers increases in cytosolic calcium concentration through the phospholipase $\mathrm{C}$ pathway, mobilizing calcium from intracellular stores. Variation of cytosolic calcium is an important feature of astrocyte activity through which these cells integrate and respond to external stimuli (Zorec et al., 2012; Bazargani and Attwell, 2016). For instance, P2Y1-mediated calcium signaling in astrocytes leads to changes in the extracellular concentration of transmitters by modulating either the activity of astrocyte transporters (Jacob et al., 2014) or the release of astrocyte transmitters or gliotransmitters, including glutamate and ATP (Araque et al., 2014). Under pathological conditions, P2Y1 expression is upregulated, and calcium signaling in activated astrocytes is usually increased (Franke et al., 2012). The best-described example is that of animal models of Alzheimer's disease. In vivo two-photon imaging showed that intracellular concentration of calcium and the frequency of calcium transients are increased in astrocytes of cortical areas including b-amyloid plaques (Kuchibhotla et al., 2009) and that inhibiting P2Y1 receptors normalizes calcium signaling (Delekate et al., 2014). These studies of Alzheimer's mice provide the only reports of intercellular propagation of calcium waves in the astrocyte syncytium in vivo. Calcium waves in astrocytes have been observed and studied extensively in cell cultures and acute slice preparations but never in vivo under physiological a pivotal role in initiating or conditions. P2Y1 plays (Giaume et al., 2010).

Several $\mathrm{P} 2 \mathrm{Y}$ receptors are expressed by microglial cells (P2Y6, P2Y12, and P2Y13), some at very high levels in resting cells (P2Y12, P2Y13). The expression of these receptors is highly dependent on the activation state of microglia. Under some conditions of activation, the expression of $\mathrm{P} 2 \mathrm{Y} 12$ and $\mathrm{P} 2 \mathrm{Y} 13$ receptors is strongly downregulated, and that of P2Y6 is increased (Haynes et al., 2006; Koizumi et al., 2007), whereas the expression of all these receptors is upregulated under other pathological conditions (Avignone et al., 2008; Kobayashi et al., 2012). The lack of specific pharmacological tools has precluded the analysis of the functional roles of P2Y13 receptors, and there are few data on its neuronal expression. Its close homolog, P2Y12, however, has received much more attention. In the brain, P2Y12 is expressed almost exclusively in microglia. Early studies using CX3CR1 1/eGFPreporter mice have demonstrated that P2Y12 is a key regulator of the dynamics of microglial process and chemotaxis (Haynes et al., 2006). P2Y12 appears to be a highly sensitive sensor of extracellular ATP, underlying response of microglial response to neuronal excitability or acute pathogenic event. For example, it has been proposed that NMDA receptor activity can lead to a local production of ATP that induces a P2Y12dependent microglial process outgrowth toward the active neuron (Li et al., 2012; Dissing-Olesen et al., 2014; Eyo et al., 2014).

UDP-sensitive P2Y6 receptors have been shown to regulate the phagocytic activity of microglia (Koizumi et al., 2007); this receptor can also induce the expression of the chemokines CCL2 and CCL3, although the downstream signaling pathway is still unclear (B. Kim et al., 2011; Morioka et al., 2013). Altogether, recent data demonstrate that astroglial and microglial purinergic receptors are central to brain functions under homeostatic and pathological conditions, yet the role of purinergic receptors expressed by other brain cells should not be neglected.

\section{PURINERGIC SIGNALING IN EPILEPSY}

The involvement of purinergic signaling in pathological situations has received much attention. This is due mainly to the common belief that extracellular ATP concentrations drastically increase under many pathological conditions, including trauma, ischemia, inflammation, periods of intense neuronal activity, and different chronic or neurodegenerative pathologies (Franke et al., 2012; Rodrigues et al., 2015). The consequences of this surge in extracellular ATP in pathological states are not fully appreciated. There are several hurdles limiting the characterization of the involvement of purinergic signaling in pathological states. First, the different mechanisms leading to ATP release are still poorly characterized. Second, ATP is rapidly metabolized in ADP and adenosine, which in turn activates their specific receptors. This dynamic process of ATP conversion is difficult to apprehend experimentally. Finally, the number of pharmacologically active molecules that can be used in vivo or ex vivo to target specifically the diverse purinergic receptors remains limited, despite some recent improvement (Bhattacharya et al., 2013). The use of genetically modified mice has provided convincing results on the involvement of purinergic receptors in diverse pathological models, indicating that some purinergic receptors could represent interesting therapeutic targets.

The involvement of purinergic signaling has been particularly investigated in the field of neuropathic pain and seizure or SE. It turns out that these two models share unexpected similarities and that microglial purinergic receptors play an active role in the development of these pathologies. The mechanisms underlying purinergic contribution to chronic pain have been reviewed elsewhere (Beggs et al., 2012; Tsuda et al., 2013). 
Increased levels of purines during epileptic seizure have been described in humans, yet this observation has been restricted to adenosine (During and Spencer, 1992). The use of electrode biosensor detecting adenosine in the CA1 area of the hippocampus has revealed a rise in adenosine levels following brief, electrically evoked electrographic seizures. However, there is still no evidence for an increase of ATP levels following seizures in this structure (Lopatar et al., 2011). In the CA3 area, dihydroxyphenylglycine, a metabotropic glutamate agonist, induces epileptiform activities and concomitant ATP release (Lopatar et al., 2015). In the two hippocampal regions, there is no correlation between the levels of extracellular ATP and adenosine, suggesting that ATP degradation by ectonucleotidase does not significantly contribute to extracellular adenosine concentration. Still, the ATP release pattern might depend on the type of stimulation eliciting epileptic activity. For example, astrocytic release of ATP can be triggered by $\mathrm{K} \quad 1$-evoked depolarization in brain slices but not by electrical stimulation, which further complicates the interpretation of these studies. If electrode biosensors allow for a direct and dynamic analysis of purine release, this technique has limitations. Indeed, even if the spatial resolution of the measurement is improved compared with the bulk analysis of ATP released in supernatant, it still provides information that may be unrelated to the concentration of ATP in the synaptic cleft or at the immediate vicinity of cells. In addition these biosensors rely on the enzymatic conversion of purine that generates peroxide. The kinetics of this conversion may be slower than the actual degradation of ATP by membrane-bound ecto-ATPase. Finally, these biosensors have been used mainly in ex vivo brain slice preparations, in which extracellular ATP levels may have been perturbed during tissue processing. Independently of whether the release of ATP is enhanced in the epileptic brain, there is general agreement that purines contribute to the pathology of epilepsy. Direct application of ATP analogs in the brain is known to evoke neuronal hyperexcitability and to promote seizure activity (Knutsen and Murray, 1997). Moreover, ATP released from astrocytes contributes to ictogenesis and epileptogenesis. On the one hand, genetic impairment of vesicular ATP release by expressing a dominantnegative soluble NSF attachment protein receptor in astrocytes delays the onset of recurrent seizure, decreases the frequency of these seizures, and reduces hippocampal damage after a pilocarpine-induced SE (Clasadonte et al., 2013). This effect is probably mediated through the control of NMDA receptor expression that is regulated by adenosine A1 receptor activation following ATP release from astrocytes (Fellin et al., 2009; Deng et al., 2011). On the other hand, it has been suggested that ATP release through PANX1 contributes to neuronal hyperexcitability in seizures because mice with PANX1 deficiency or silencing are less prone to kainate- or pilocarpin-evoked SE (Santiago et al., 2011). Finally, there is a profound remodeling of the expression of hippocampal P2 receptors following SE in rodents (Avignone et al., 2008; Engel et al., 2016); this will be the focus of the following paragraphs.

\section{P2X Receptors in Epilepsy}

Because of their excitatory properties, their activation during episode of high neuronal activity, and their expression in microglial cells, the involvement of ionotropic $\mathrm{P} 2 \mathrm{X}$ receptors in tissue remodeling after the induction of SE has received special attention. After SE, a local inflammatory reaction occurs in brain areas that have been the most active during the seizure episode, and this inflammation persists for days or weeks. There is now strong evidence that this inflammatory response promotes neuronal damage and contributes to long-lasting alteration of local network properties (Devinsky et al., 2013; Marchi et al., 2014). IL-1b and TNF-a are key proinflammatory cytokines, which, in the CNS, can sustain neuronal hyperexcitability, and their involvement in the initiation of seizure and epileptogenesis was proposed several years ago (Vezzani et al., 2008). The fact that P2X7 activity is the main trigger of $\mathrm{IL}-1 \mathrm{~b}$ processing and contributes to TNF-a production led to investigating the role of these receptors in epilepsy. In human specimens from patients suffering with focal cortical dysplasia (FCD), P2X7 mRNA and protein expressions were increased vs. control samples. This was accompanied by an increased immunoreactivity against $\quad \mathrm{LL}-1 \mathrm{~b}$ in microglia and also in dysmorphic neurons and balloon cells, which are characteristic cells of FCD (Wei et al., 2015). The roles of P2X7 in epilepsy have been investigated in different animal models in which the modulation of the receptor activity was performed with different approaches, either pharmacological or genetic. Opposite results were reported when SE was induced through systemic injection of proconvulsive agents or through direct intra-amygdala injection of kainate. In the pilocarpine-evoked SE model, P2X7 appeared to have protective properties. Indeed, inhibition of P2X7 activity with either specific antagonists or P2X7deficient mice increased seizure susceptibility after pilocarpine injection. P2X7-anticonvulsive effects were linked to PANX1 because siRNA-mediated downregulation of PANX1 also reduced the threshold of seizure apparition (Kim and Kang, 2011). It has been suggested that the protective effect of $\mathrm{P} 2 \mathrm{X} 7$ receptor in pilocarpineinduced SE could be mediated through TNF-a pathways, at least in the CA3 area (J.E. Kim et al., 2011). In a region-specific manner, $\mathrm{P} 2 \mathrm{X} 7$ receptors control the hippocampal nonapoptotic astrocyte death after pilocarpineinduced SE (Kim et al., 2015).

On the other hand, P2X7 activation appears to have proconvulsive effects when SE is triggered by an intraamygdala injection of KA. In this model, P2X7-deficient mice showed reduced electrographic seizure during SE, and pretreatment with $\mathrm{P} 2 \mathrm{X} 7$ antagonists (brilliant blue $\mathrm{G}$ or A-438079) reduced behavioral seizures, neuronal cell death in the hippocampus, and increase of IL-1b triggered by SE. Treatment with a combination of a classical anticonvulsivant (lorazepam) and A-438079 during the SE 
refractory period, a period during which SE cannot be blocked by anticonvulsants alone, efficiently stopped the SE (for review see Jimenez-Mateos et al., 2015). The regulation of $\mathrm{P} 2 \mathrm{X} 7$ expression in this model is controlled by micro-RNA-22, which has anticonvulsive effects by inhibiting P2X7 expression (Jimenez-Mateos et al., 2015). Whether this regulation holds true also in humans has not been documented.

The reason for the discrepancies between the two models is not clear. The same antagonists and the same strain of P2X7-deficient mice were used in both cases; however, these two experimental models of SE are very different, and it is possible that, in the pilocarpine model, the peripheral mode of administration involves a P2X7dependent intermediary step that is not activated when $\mathrm{SE}$ is induced by direct intra-amygdala injection of kainate. It is worth noting that adhesion of circulating leukocytes on endothelial cells of cerebral blood vessels is probably an initial and mandatory step of SE induction in the pilocarpine model (Fabene et al., 2008). A recent study in rats showed that, 3 months after systemic kainate injections, treatment with a new P2X7 antagonist that crosses the blood-brain barrier decreased the severity of spontaneous recurrent seizures (Amhaoul et al., 2016). Although the seizure frequency remained unaltered by this new $\mathrm{P} 2 \mathrm{X} 7$ antagonist, this study further strengthens the idea that blocking P2X7 might have beneficial effects in regulating seizure during not only the acute but also the chronic phases of the disease.

P2X7 may thus appear as a potential therapeutic target to reduce the burden of seizures. However, several technical issues with respect to the results discussed in this Review should be kept in mind. First, the antagonists used in these studies are specific for P2X7 receptors compared with other P2X receptors or other receptors and channels but may show off-target activity. Such a case was reported recently for a P2X1 antagonist that also inhibits the activity of CCR5 and CXCR4 (Giroud et al., 2015). Second, the tissue and cellular distribution of $\mathrm{P} 2 \mathrm{X} 7$ is still unclear; antibodies and mouse reporter gene lack specificity or can reasonably be questioned. With respect to the Gensat P2X7-GFP reporter mouse (http:// www.gensat.org/imagenavigator.jsp?imagelD=36838), there are strong discrepancies between the pattern of expression of GFP in this mouse strain and mRNA tissue distribution of the receptor that can be visualized in the Allen brain atlas in situ hybridization database (http:// mouse.brain-map.org/gene/show/18206). Moreover, it is surprising that no expression of GFP in microglial cells can be observed in this mouse because there are clear demonstrations that $\mathrm{P} 2 \mathrm{X} 7$ is functionally expressed in microglial cells under physiological conditions (see above). Finally, whether $\mathrm{P} 2 \mathrm{X} 7$ is efficiently deleted in the two commonly used P2X7-deficient mice is still (Taylor et al., 2009). For all these reasons, further work is required to establish unambiguously whether $\quad \mathrm{P} 2 \mathrm{X} 7$ is a viable therapeutic target in epilepsy. Particularly, investigating the involvement of P2X7 in seizure activity and chronic epilepsy in conditional knockout mice will be an essential step. There is a common agreement that the expression of P2X7 is enhanced following SE in the hippocampus. Whether this expression is restricted to microglia, as functionally demonstrated (Avignone et al., 2008), or is also present in neurons and astrocytes requires a clear examination. Finally, it is important to note that all clinical trials testing the effectiveness of P2X7 antagonists have failed to demonstrate any beneficial effect in rheumatoid arthritis (Keystone et al., 2012), despite the clear demonstration of involvement of this receptor in animal models of the disease.

$\mathrm{P} 2 \mathrm{X} 4$ is the only other $\mathrm{P} 2 \mathrm{X}$ receptor that has been studied for its potential involvement in epilepsy. As for $\mathrm{P} 2 \mathrm{X} 7$, there are important discrepancies in the literature, mainly regarding whether $\mathrm{P} 2 \mathrm{X} 4$ expression is up- or downregulated in the hippocampus following SE. In mice, two studies showed no change or a decrease of P2X4 immunostaining within $24 \mathrm{hr}$ post-SE, evoked either by systemic pilocarpine or by intra-amygdala kainate injection (Dona et al., 2009; Engel et al., 2012). A similar finding was also reported in seizure-sensitive compared with seizure-resistant gerbil hippocampus (Kang et al., 2003). However, no specificity for the P2X4 antibodies used in any of these studies was provided. Another study using intraperitoneal injection of kainate to elicit SE demonstrated an increase of the transcription and protein expression in the hippocampus 24 and $48 \mathrm{hr}$ post-SE (Ulmann et al., 2013). Particularly, upregulated P2X4 receptors were localized in activated microglial cells in the stratum radiatum. In this study, the specificity of P2X4 antibody staining was confirmed in P2X4-deficient mice.

Furthermore, Western blot experiments performed on purified hippocampal microglia clearly demonstrated a de novo expression of P2X4 in microglia $48 \mathrm{hr}$ after the induction of SE. Involvement of P2X4 in epileptogenesis was also investigated with the P2X4-deficient mice. The data show a reduction of distinct hallmarks of microglial activation after the induction of SE in the P2X4-deficient mice, including a reduction of cell density and morphological changes. Analysis of microglia electrophysiological properties in acute hippocampal slices revealed that the upregulation of Kv1.3-mediated outward K 1 currents normally occurring in activated microglia mice was reduced in epileptic $\mathrm{P} 2 \mathrm{X} 4$-deficient mice, yet the functional upregulation of $\mathrm{P} 2$ receptors (i.e., $\mathrm{P} 2 \mathrm{X} 7$, $\mathrm{P} 2 \mathrm{Y} 12$, and P2Y6) was not altered by the deletion of $\mathrm{P} 2 \mathrm{X} 4$. In addition, a reduction in the expression of different proinflammatory genes and a lower neuronal cell death in the CAl area were also reported. Although SE was not analyzed by EEG recordings in P2X4-deficient mice, no difference of susceptibility to kainate-induced SE assessed by scoring behavioral seizures was observed between wild-type and P2X4-deficient mice. Whether P2X4-deficient mice can develop spontaneous recurrent seizure has not been determined. Thus, even though both microglial activation and neuronal damage are significantly attenuated by the inactivation of this receptor, the role of P2X4 must be further substantiated by EEG recordings during acute and chronic phases of epilepsy. In 
addition, P2X4 conditional allele deletion to inactivate $\mathrm{P} 2 \mathrm{X} 4$ in either neurons or microglia should also be performed. Indeed, P2X4 is expressed in hippocampal neurons, where its activation is triggered by episodes of high neuronal activity (Sim et al., 2006) and could lead to hyperexcitability, which in turn could promote microglial activation or neuronal death. On the other hand, as documented in the neuropathic pain model (Beggs et al., 2012), de novo expression of P2X4 in microglia after SE could control the release of BDNF and KCC2 downregulation, thereby inducing local hyperexcitability and promoting epileptogenesis. Clearly, there is a crucial requirement for specific $\mathrm{P} 2 \mathrm{X} 4$ antagonists and for more targeted genetic approaches to clarify the actual roles of $\mathrm{P} 2 \mathrm{X} 4$ in epilepsy.

\section{P2Y Receptors in Epilepsy}

The role of $\mathrm{P} 2 \mathrm{Y}$ receptors in epilepsy has received little attention. From a purely neuronal point of view, there is little evidence supporting a role for these receptors in mediating hyperexcitability or epileptogenesis. However, functional excitatory P2Y1 receptors are expressed by subpopulations of inhibitory interneurons in the hippocampus (Bowser and Khakh, 2004). Some of these interneurons degenerate after SE (Dinocourt et al., 2003), and this could lead to a modification of the P2Y1 regulation of the excitation/inhibition balance in the hippocampal neuronal network.

The expression of P2Y receptors in glia and their remodeling under pathological conditions suggest that these receptors may contribute to phenotypic changes taking place after seizures. Supporting this idea, P2Y12 receptors are functionally upregulated in microglia after $\mathrm{SE}$, and this leads to increased process motility toward a source of ATP (Avignone et al., 2008). Other aspects of microglia process motility (e.g., basal motility or process extension toward a laser-induced lesion) are not affected in this model (Avignone et al., 2015). These studies were performed with either local application of agonists or laser-evoked microlesion in acute slices after SE induction in vivo. Eyo and coworkers (2014) also demonstrated, in vivo, that P2Y12 receptor-mediated elongation of microglia processes toward active dendrites are enhanced after SE. This phenomenon was impaired in P2Y12-deficient mice, and, remarkably, these mice showed a worsening of kainate-induced seizures, suggesting that microglial P2Y12 signaling has a beneficial effect on the outcome of the disease.

Microglial P2Y6 receptors are also upregulated after SE (Avignone et al., 2008), but the consequences of this upregulation on epilepto- and ictogenesis have not been evaluated. These receptors control the phagocytic function of microglial cells (Koizumi et al., 2007), so it is important to test whether P2Y6 contributes to the phagocytosis of hippocampal neurons after SE as well as to the regulation of adult neurogenesis in the dentate gyrus (Sierra et al., 2010), which is also affected after seizures (Sierra et al., 2015).
Astrocytic purinergic signaling in epilepsy has received little attention despite the fact that $\mathrm{P} 2 \mathrm{Y} 1$ receptors control calcium signaling in astrocytes and contribute to glutamate-mediated gliotransmission (see above). In the hippocampus, the astrocytic release of glutamate following P2Y1 activation is controlled by TNF-a and prostaglandins (Domercq et al., 2006). Accordingly, this form of gliotransmission is enhanced in the inflammatory context of a mouse model of multiple sclerosis and leads to alterations of synaptic functions and impairment of contextual learning and memory (Habbas et al., 2015). TNFa and prostaglandin signaling are rapidly upregulated after SE (Avignone et al., 2008), so it is very likely that altered gliotransmission will contribute to the remodeling of the hippocampus during epileptogenesis and to the generation of seizures. In an in vitro model of focal seizures, calcium elevation in astrocytes, partially dependent on $\mathrm{P} 2$ receptors, contributes to drive neurons to the threshold of ictal but not interictal events (Gomez-Gonzalo et al., 2010). Moreover, calcium signaling is enhanced in cortical astrocytes in vivo during and up to 3 days after pilocarpineinduced SE (Ding et al., 2007). Unfortunately, despite the fact that this enhanced calcium signaling favors the release of astrocytic glutamate and SE-induced neuronal death, the contribution of $\mathrm{P} 2 \mathrm{Y}$ receptors has not been tested. A more recent study on a model of kindling in the rat also indicated enhanced calcium signaling in astrocytes that depends on P2Y1 receptor activation (Alvarez-Ferradas et al., 2015). In agreement with the pilocarpine model, processes downstream of the kindling-evoked calcium signaling include mGluR5-dependent increase of presynaptic glutamate release probability and NMDA receptordependent enhanced neuronal excitability. ATP released by microglia in hippocampal slices of na€ıve animalscan rapidly mobilize this signaling cascade through the activation of astrocyte P2Y1 receptors, the release of astrocyte glutamate, and the activation of mGluR5 receptors on presynaptic glutamatergic terminals, leading to an enhancement of excitability and favoring the appearance of epileptiform activities (Pascual et al., 2012). These results support the hypothesis of an active role of astrocytic P2Y1 receptors in epileptogenesis. However, specific inhibition or invalidation at specific stages of the disease is still required to establish more clearly the actual impact of this enhanced P2Y1 signaling. Moreover, a careful examination of the involvement of other P2Y receptors that may be upregulated in reactive astrocytes is required.

\section{CONCLUSIONS AND PERSPECTIVES}

Increasing evidence indicates that this glial reactivity is actively involved in remodeling of the epileptic brain (Matute and Cavaliere, 2011; Steinhauser and Boison, 2012; Devinsky et al., 2013; Heuser et al., 2014) and that ATP is a danger signal in many disorders, including epilepsy (Rodrigues et al., 2015). Here, we have reviewed several modifications of purinergic signaling pathways that have been observed in animal models of epilepsy, and we 
believe that, as fundamental components of neuron-glia interactions, purinergic receptors represent promising therapeutic targets to cure or to control the disease better. Unlike glutamate and GABA receptors, purinergic receptors are not expressed by all neurons of the brain. Some of these receptors are expressed almost exclusively by astrocytes or microglia and control several key functions of these glial cells. Moreover, some of these receptors are selectively upregulated in glial cells after these cells are activated under pathological conditions. This is the case, for instance, for P2X4 in microglia after SE (UImann et al., 2013). However, the repertoire of purinergic receptors expressed by astrocytes and by microglia at different stages of the disease is still largely unknown and should be carefully determined. Functional studies to establish the roles of these receptors will certainly be an important step, but the lack of specific pharmacological tools will be an obstacle. An initial transcriptome analysis to identify the set of genes up- or downregulated in astrocytes and in microglia at different stages of the disease appears to be essential before designing genetic and functional strategies to understand better the specific roles of purinergic receptors during the time course of reactive gliosis occurring in epilepsy.

\section{ACKNOWLEDGMENTS}

The authors thank all their team members who have contributed to the study of purinergic signaling pathways in microglia and astrocytes over the past 10 years.

\section{CONFLICT OF INTEREST STATEMENT}

The authors have no conflicts of interest to declare.

\section{ROLE OF AUTHORS}

FR and EA contributed equally to the writing of this Review.

\section{REFERENCES}

Alvarez-Ferradas C, Morales JC, Wellmann M, Nualart F, Roncagliolo M, Fuenzalida M, Bonansco C. 2015. Enhanced astroglial Ca21 signaling increases excitatory synaptic strength in the epileptic brain. Glia 63: 1507-1521.

Amhaoul H, Ali I, Mola M, Van EA, Szewczyk K, Missault S, Bielen K, Kumar-Singh S, Rech J, Lord B, Ceusters M, Bhattacharya A, Dedeurwaerdere S. 2016. P2X7 receptor antagonism reduces the severity of spontaneous seizures in a chronic model of temporal lobe epilepsy. Neuropharmacology 105:175-185.

Araque A, Carmignoto G, Haydon PG, Oliet SH, Robitaille R, Volterra A. 2014. Gliotransmitters travel in time and space. Neuron 81:728-739.

Arnoux I, Audinat E. 2015. Fractalkine signaling and microglia functions in the developing brain. Neural Plast 2015:689404.

Avignone E, Ulmann L, Levavasseur F, Rassendren F, Audinat E. 2008. Status epilepticus induces a particular microglial activation state characterized by enhanced purinergic signaling. J Neurosci 28:9133-9144.

Avignone E, Lepleux M, Angibaud J, Nagerl UV. 2015. Altered morphological dynamics of activated microglia after induction of status epilepticus. J Neuroinflammation 12:202.

Avsar E, Empson RM. 2004. Adenosine acting via A1 receptors controls the transition to status epilepticus-like behaviour in an in vitro model of epilepsy. Neuropharmacology 47:427-437.
Bao L, Locovei S, Dahl G. 2004. Pannexin membrane channels are mechanosensitive conduits for ATP. FEBS Lett 572:65-68.

Baulac M, Pitkanen A. 2008. Research priorities in epilepsy for the next decade: a representative view of the European scientific community. Epilepsia 50:571-578.

Baxter AW, Choi SJ,Sim JA, North RA. 2011. Role of P2X4 receptors in synaptic strengthening in mouse CA1 hippocampal neurons. Eur $\mathrm{J}$ Neurosci 34:213-220.

Bazargani N, Attwell D. 2016. Astrocyte calcium signaling: the third wave. Nat Neurosci 19:182-189.

Beckel JM, Argall AJ, Lim JC, Xia J, Lu W, Coffey EE, Macarak EJ, Shahidullah M, Delamere NA, Zode GS, Sheffield VC, Shestopalov VI, Laties AM, Mitchell CH. 2014. Mechanosensitive release ódenosine 50triphosphate through pannexin channels and mechanosensitive upregulation of pannexin channels in optic nerve head astrocytes: a mechanism for purinergic involvement in chronic strain. Glia 62:14861501.

Bedner P, Dupper A, Huttmann K, Muller J, Herde MK, Dublin P, Deshpande T, Schramm J, Haussler U, Haas CA, Henneberger C, Theis M, Steinhauser C. 2015. Astrocyte uncoupling as a cause of human temporal lobe epilepsy. Brain 138:1208-1222.

Beggs S, Trang T, Salter MW. 2012. P2X4R 1 microglia drive neuropathic pain. Nat Neurosci 15:1068-1073.

Bergles DE, Richardson WD. 2015. Oligodendrocyte development and plasticity. Cold Spring Harbor Perspect Biol 8.

Bhattacharya A, Wang Q, Ao H, Shoblock JR, Lord B, Aluisio L, Fraser I, Nepomuceno D, Neff RA, Welty N, Lovenberg TW, Bonaventure $P$, Wickenden AD, Letavic MA. 2013. Pharmacological characterization of a novel centrally permeable $\mathrm{P} 2 \times 7$ receptor antagonist: JNJ47965567. Br J Pharmacol170:624-640.

Bo X, Jiang LH, Wilson HL, Kim M, Burnstock G, Surprenant A, North RA. 2003. Pharmacological and biophysical properties of the human P2X5 receptor. Mol Pharmacol63:1407-1416.

Boison D. 2015. Adenosinergic signaling in epilepsy. Neuropharmacology [E-pub ahead of print] doi: 10.1016/j.neuropharm.2015.08.046

Bowser DN, Khakh BS. 2004. ATP excites interneurons and astrocytes to increase synaptic inhibition in neuronal networks. J Neurosci 24: 8606-8620.

Bowser DN, Khakh BS. 2007. Vesicular ATP is the predominant cause of intercellular calcium waves in astrocytes. J Gen Physioll 29:485-491.

Burnstock G. 2006a. Historical review: ATP as a neurotransmitter. Trends PharmacolSci 27:166-176.

Burnstock G. 2006b. Pathophysiology and therapeutic potential of purinergic signaling. PharmacoIRev 58:58-86.

Butt AM. 2011. ATP: a ubiquitous gliotransmitter integrating neuronglial networks. Semin Cell Dev Biol 22:205-213.

ChessellIP, Hatcher JP, Bountra C, Michel AD, Hughes JP, Green P, Egerton J, Murfin M, Richardson J, Peck WL, GrahamesCB, Casula MA, Yiangou Y, Birch R, Anand P, Buell GN. 2005. Disruption of the $\mathrm{P} 2 \mathrm{X} 7$ purinoceptor gene abolishes chronic inflammatory and neuropathic pain. Pain 114:386-396.

Clasadonte J,Dong J, Hines DJ, Haydon PG. 2013. Astrocyte control of synaptic NMDA receptors contributes to the progressive development of temporal lobe epilepsy. Proc Natl Acad Sci U S A 110:1754017545.

Collo G, North RA, Kawashima E, Merlo-Pich E, Neidhart S, Surprenant A, Buell G. 1996. Cloning OF P2X5 and P2X6 receptors and the distribution and properties of an extended family of ATP-gated ion channels. J Neurosci 16:2495-2507.

Compan V, Ulmann L, Stelmashenko O, Chemin J, Chaumont S, Rassendren F. 2012. P2X2 and P2X5 subunits define a new heteromeric receptor with P2X7-like properties. J Neurosci 32:4284-4296.

De Simoni MG, Perego C, Ravizza T, Moneta D, Conti M, Marchesi F, De Luigi A, Garattini S, Vezzani A. 2000. Inflammatory cytokines 
and related genes are induced in the rat epilepticus. Eur J Neurosci 12:2623-2633.

hippocampus by limbic status

Delekate A, Fuchtemeier $M$, Schumacher T, Ulbrich C, Foddis $M$ Petzold GC. 2014. Metabotropic P2Y1 receptor signalling mediates astrocytic hyperactivity in vivo in an Alzheimer's disease mouse model. Nat Commun 5:5422.

Deng Q, Terunuma M, Fellin T, Moss SJ, Haydon PG. 2011. Astrocytic activation of A1 receptors regulates the surface expression of NMDA receptors through a Src kinase dependent pathway. Glia 59:1084-1093.

Devinsky O, Vezzani A, Najjar S, De Lanerolle NC, Rogawski MA. 2013. Glia and epilepsy: excitability and inflammation. Trends Neurosci 36:174-184.

Ding S, Fellin T, Zhu Y, Lee SY, Auberson YP, Meaney DF, Coulter DA, Carmignoto G, Haydon PG. 2007. Enhanced astrocytic Ca 21 sig nals contribute to neuronal excitotoxicity after status epilepticus. J Neurosci 27:10674-10684.

Dinocourt C, Petanjek Z, Freund TF, Ben Ari Y, Esclapez M. 2003 Loss of interneurons innervating pyramidal cell dendrites and axon initial segments in the CA1 region of the hippocampus following pilocarpine-induced seizures. J Comp Neurol 459:407-425.

Dissing-Olesen L, LeDue JM, Rungta RL, Hefendehl JK, Choi HB, MacVicar BA. 2014. Activation of neuronal NMDA receptors triggers transient ATP-mediated microglial process outgrowth. J Neurosci 34: 10511-10527.

Domercq M, Brambilla L, Pilati E, Marchaland J, Volterra A, Bezzi P. 2006. P2Y1 receptor-evoked glutamate exocytosis from astrocytes: control by tumor necrosis factor-alpha and prostaglandins. J Biol Chem 281:30684-30696.

Domercq M, Perez-Samartin A, Aparicio D, Alberdi E, Pampliega O, Matute C. 2010. P2X7 receptors mediate ischemic damage to oligodendrocytes. Glia 58:730-740.

Dona F, Ulrich H, Persike DS, Conceicao IM, Blini JP, Cavalheiro EA, Fernandes MJ. 2009. Alteration of purinergic $P 2 X 4$ and $P 2 X 7$ receptor expression in rats with temporal-lobe epilepsy induced by pilocarpine. Epilepsy Res 83:157-167.

During MJ, Spencer DD. 1992. Adenosine: a potential mediator of seizure arrest and postictal refractoriness. Ann Neurol 32:618-624.

Egan TM, Khakh BS. 2004. Contribution of calcium ions to P2X channel responses. J Neurosci 24:3413-3420.

Engel T, Jimenez-Pacheco A, Miras-Portugal MT, Diaz-Hernandez M, Henshall DC. 2012. P2X7 receptor in epilepsy; role in pathophysiology and potential targeting for seizure control. Int J Physiol Pathophysiol Pharmacol 4:174-187.

Engel T, Alves M, Sheedy C, Henshall DC. 2016. ATPergic signalling during seizures and epilepsy. Neuropharmacology. 104:140-153.

Etherington LA, Frenguelli BG. 2004. Endogenous adenosine modulates epileptiform activity in rat hippocampus in a receptor subtypedependent manner. Eur J Neurosci 19:2539-2550.

Eyo UB, Peng J, Swiatkowski P, Mukherjee A, Bispo A, Wu LJ. 2014 Neuronal hyperactivity recruits microglial processes via neuronal NMDA receptors and microglial P2Y12 receptors after status epilepticus. J Neurosci 34:10528-10540.

Fabene PF, Navarro MG, Martinello M, Rossi B, Merigo F, Ottoboni L, Bach S, Angiari S, Benati D, Chakir A, Zanetti L, Schio F, Osculati A Marzola P, Nicolato E, Homeister JW, Xia L, Lowe JB, McEver RP, Osculati F, Sbarbati A, Butcher EC, Constantin G. 2008. A role for leukocyte-endothelial adhesion mechanisms in epilepsy. Nat Med 14: 1377-1383.

Fellin T, Halassa MM, Terunuma M, Succol F, Takano H, Frank M, Moss SJ, Haydon PG. 2009. Endogenous nonneuronal modulators of synaptic transmission control cortical slow oscillations in vivo. Proc Natl Acad Sci U S A 106:15037-15042.
Fields RD. 2011a. Nonsynaptic and nonvesicular ATP release from neurons and relevance to neuron-glia signaling. Semin Cell Dev Biol 214-219.

Fields RD. 2011b. Signaling by neuronal swelling. Sci Signal 4:tr1. Franke H, Verkhratsky A, Burnstock G, Illes P. 2012. Pathophysiology of astroglial purinergic signalling. Purinergic Signal 8:629-657.

Giaume C, Koulakoff A, Roux L, Holcman D, Rouach N. 2010. Astroglial networks: a step further in neuroglial and gliovascular interactions. Nat Rev Neurosci 11:87-99.

Giroud C, Marin M, Hammonds J, Spearman P, Melikyan GB. 2015 P2X1 receptor antagonists inhibit HIV-1 fusion by blocking virus-coreceptor interactions. J J Virol 89:9368-9382.

Gomez-Gonzalo M, Losi G, Chiavegato A, Zonta M, Cammarota M, Brondi M, Vetri F, Uva L, Pozzan T, de CM, Ratto GM, Carmignoto G. 2010. An excitatory loop with astrocytes contributes to drive neurons to seizure threshold. PLoS Biol 8:e1000352.

Habbas S, Ango F, Daniel H, Galante M. 2011. Purinergic signaling in the cerebellum: Bergmann glial cells express functional ionotropic P2X7 receptors. Glia 59:1800-1812.

Habbas S, Santello M, Becker D, Stubbe H, Zappia G, Liaudet N, Klaus FR, Kollias G, Fontana A, Pryce CR, Suter T, Volterra A. 2015. Neuroinflammatory TNFa impairs memory via astrocyte signaling. Cell 163:1730-1741.

Hamilton N, Vayro S, Kirchhoff F, Verkhratsky A, Robbins J, Gorecki DC, Butt AM. 2008. Mechanisms of ATP- and glutamate-mediated calcium signaling in white matter astrocytes. Glia 56:734-749.

Hanisch UK, Kettenmann H. 2007. Microglia: active sensor and versatile effector cells in the normal and pathologic brain. Nat Neurosci 10:1387-1394.

Hanstein R, Negoro H, Patel NK, Charollais A, Meda P, Spray DC, Suadicani SO, Scemes E. 2013. Promises and pitfalls of a Pannexin1 transgenic mouse line. Front Pharmacol 4:61.

Haynes SE, Hollopeter G, Yang G, Kurpius D, Dailey ME, Gan WB, Julius D. 2006. The $\mathrm{P} 2 \mathrm{Y} 12$ receptor regulates microglial activation by extracellular nucleotides. Nat Neurosci 9:1512-1519.

Hesdorffer DC, Logroscino G, Benn EK, Katri N, Cascino G, Hauser WA. 2011. Estimating risk for developing epilepsy: a population-based study in Rochester, Minnesota. Neurology 76:23-27.

Heuser K, Szokol K, Tauboll E. 2014. [The role of glial cells in epilepsy]. Tidsskr Nor Laegeforen 134:37-41.

Hirayama Y, Ikeda-Matsuo Y, Notomi S, Enaida H, Kinouchi $\mathrm{H}$, Koizumi S. 2015. Astrocyte-mediated ischemic tolerance. J Neurosci 35:3794-3805.

Holton P. 1959. The liberation of adenosine triphosphate on antidromic stimulation of sensory nerves. J Physiol 145:494-504.

Huber A, Padrun V, Deglon N, Aebischer P, Mohler H, Boison D. 2001. Grafts of adenosine-releasing cells suppress seizures in kindling epilepsy. Proc Natl Acad Sci U S A 98:7611-7616.

Imura Y, Morizawa Y, Komatsu R, Shibata K, Shinozaki Y, Kasai H, Moriishi K, Moriyama Y, Koizumi $\quad$ S. 2013. Microglia release ATP by exocytosis. Glia 61:1320-1330.

Islam MR, Uramoto H, Okada T, Sabirov RZ, Okada Y. 2012. Maxianion channel and pannexin 1 hemichannel constitute separate pathways for swelling-induced ATP release in murine L929 fibrosarcoma cells. Am J Physiol Cell Physiol 303:C924-C935.

Jabs R, Matthias K, Grote A, Grauer M, Seifert G, Steinhauser C. 2007 Lack of P2X receptor mediated currents in astrocytes and GluR type glial cells of the hippocampal CA1 region. Glia 55:1648-1655.

Jacob PF, Vaz SH, Ribeiro JA, Sebastiao AM. 2014. P2Y1 receptor inhibits GABA transport through a calcium signalling-dependent mechanism in rat cortical astrocytes. Glia 62:1211-1226.

Jimenez-Mateos EM, Arribas-Blazquez M, Sanz-Rodriguez A Concannon C, Olivos-Ore LA, Reschke CR, Mooney CM, Mooney C, Lugara E, Morgan J, Langa E, Jimenez-Pacheco A, Silva LF, Mesuret G, Boison D, Miras-Portugal MT, Letavic M, Artalejo AR, 
Bhattacharya A, Diaz-Hernandez M, Henshall DC, Engel T. 2015 microRNA targeting of the P2X7 purinoceptor opposes a contralateral epileptogenic focus in the hippocampus. Sci Rep 5:17486.

Jo YH, Donier E, Martinez A, Garret M, Toulme E, Boue-Grabot E. 2011. Cross-talk between $P 2 X 4$ and gamma-aminobutyric acid type $A$ receptors determines synaptic efficacy at a central synapse. J Biol Chem 286:19993-20004.

Kang TC, An SJ, Park SK, Hwang IK, Won MH. 2003. P2X2 and $\mathrm{P} 2 \mathrm{X} 4$ receptor expression is regulated by a GABA receptor-mediated mechanism in the gerbil hippocampus. Brain Res Mol Brain Res 116 168-175.

Kettenmann H, Hanisch UK, Noda M, Verkhratsky A. 2011. Physiology of microglia. Physiol Rev 91:461-553.

Kettenmann H, Kirchhoff F, Verkhratsky A. 2013. Microglia: new roles for the synaptic stripper. Neuron 77:10-18.

Keystone EC, Wang MM, Layton M, Hollis S, Mclnnes IB. 2012. Clinical evaluation of the efficacy of the $\mathrm{P} 2 \mathrm{X} 7$ purinergic receptor antagonist AZD9056 on the signs and symptoms of rheumatoid arthritis in patients with active disease despite treatment with methotrexate or sulphasalazine. Ann Rheum Dis 71:1630-1635.

Khakh BS, North RA. 2012. Neuromodulation by extracellular ATP and P2X receptors in the CNS. Neuron 76:51-69.

Kim B, Jeong HK, Kim JH, Lee SY, Jou I, Joe EH. 2011. Uridine 5 Q diphosphate induces chemokine expression in microglia and astrocytes through activation of the P2Y6 receptor. J Immunol 186:3701-3709.

Kim JE, Kang TC. 2011. The P2X7 receptor-pannexin-1 complex decreases muscarinic acetylcholine receptor-mediated seizure susceptibility in mice. J Clin Invest 121:2037-2047.

Kim JE, Ryu HJ, Kang TC. 2011. P2X7 receptor activation ameliorates CA3 neuronal damage via a tumor necrosis factor-alpha-mediated pathway in the rat hippocampus following status epilepticus. J Neuroinflammation 8:62.

Kim JY, Ko AR, Kim JE. 2015. P2X7 receptor-mediated PARP1 activity regulates astroglial death in the rat hippocampus following status epilepticus. Front Cell Neurosci 9:352.

Knutsen LJS, Murray TF. 1997. Adenosine and ATP in epilepsy. In: Jacobson KA, Jarvis MF (eds) Purinergic appraoches in experimental therapeutics. Wiley-Lyss, New York, pp 423-447.

Kobayashi K, Yamanaka H, Yanamoto F, Okubo M, Noguchi K. 2012. Multiple P2Y subtypes in spinal microglia are involved in neuropathic pain after peripheral nerve injury. Glia 60:1529-1539.

Koizumi S, Shigemoto-Mogami Y, Nasu-Tada K, Shinozaki Y, Ohsawa K, Tsuda M, Joshi BV, Jacobson KA, Kohsaka S, Inoue K. 2007. UDP acting at P2Y6 receptors is a mediator of microglial phagocytosis. Nature 446:1091-1095.

Kuchibhotla KV, Lattarulo CR, Hyman BT, Bacskai BJ. 2009. Synchronous hyperactivity and intercellular calcium waves in astrocytes in Alzheimer mice. Science 323:1211-1215.

Lalo U, Pankratov Y, Wichert SP, Rossner MJ, North RA, Kirchhoff F, Verkhratsky A. 2008. P2X1 and P2X5 subunits form the functional P2X receptor in mouse cortical astrocytes. J Neurosci 28:5473-5480.

Lazarowski ER. 2012. Vesicular and conductive mechanisms of nucleotide release. Purinergic Signal 8:359-373.

Li Y, Du XF, Liu CS, Wen ZL, Du JL. 2012. Reciprocal regulation between resting microglial dynamics and neuronal activity in vivo. Dev Cell 23:1189-1202.

Liu HT, Toychiev AH, Takahashi N, Sabirov RZ, Okada Y. 2008 Maxianion channel as a candidate pathway for osmosensitive ATP release from mouse astrocytes in primary culture. Cell Res 18:558-565.

Lohman AW, Isakson BE. 2014. Differentiating connexin hemichannels and pannexin channels in cellular ATP release. FEBS Lett 588:13791388.

Lopatar J, Dale N, Frenguelli BG. 2011. Minor contribution of ATP P2 receptors to electrically-evoked electrographic seizure activity in hippo- campal slices: evidence from purine biosensors and P2 receptor agonists and antagonists. Neuropharmacology 61:25-34.

Lopatar J, Dale N, Frenguelli BG. 2015. Pannexin-1-mediated ATP release from area CA3 drives Neuropharmacology 93:219-228.

Maitre B, Magnenat S, Heim V, Ravanat C, Evans RJ, de la SH, Gachet C, Hechler B. 2015. The P2X1 receptor is required for neutrophil extravasation during lipopolysaccharide-induced lethal endotoxemia in mice. J Immunol 194:739-749.

Maldonado PP, Angulo MC. 2015. Multiple modes of communication between neurons and oligodendrocyte precursor cells. Neuroscientist 21:266-276.

Marchi N, Granata T, Janigro D. 2014. Inflammatory pathways of seizure disorders. Trends Neurosci 37:55-65.

Matute C. 2008. P2X7 receptors in oligodendrocytes: a novel target for neuroprotection. Mol Neurobiol 38:123-128.

Matute C, Cavaliere F. 2011. Neuroglial interactions mediated by purinergic signalling in the pathophysiology of CNS disorders. Semin Cell Dev Biol 22:252-259.

Morioka N, Tokuhara M, Harano S, Nakamura Y, Hisaoka-Nakashima K, Nakata Y. 2013. The activation of P2Y6 receptor in cultured spinal microglia induces the production of CCL2 through the MAP kinasesNF-kappaB pathway. Neuropharmacology 75:116-125.

Noebels JL, Rogawski M, Olsen RW, Delgado-Escueta AV. 2012. The next decade of research in the basic mechanisms of the epilepsies. In: Noebels JL, Avoli M, Rogawski M, Olsen RW, Delgado-Escueta AV, editors. Jasper's basic mechanisms of the epilepsies. Bethesda, MD: Oxford University Press. p 3-11.

Orellana JA, Stehberg J. 2014. Hemichannels: new roles in astroglial function. Front Physiol 5:193.

Oya M, Kitaguchi T, Yanagihara $\mathrm{Y}$, Numano R, Kakeyama M, Ikematsu K, Tsuboi T. 2013. Vesicular nucleotide transporter is involved in ATP storage of secretory lysosomes in astrocytes. Biochem Biophys Res Commun 438:145-151.

Pankratov YV, Lalo UV, Krishtal OA. 2002. Role for P2X receptors in long-term potentiation. J Neurosci 22:8363-8369.

Pankratov Y, Lalo U, Verkhratsky A, North RA. 2007. Quantal release of ATP in mouse cortex. J Gen Physiol 129:257-265.

Pannicke T, Fischer W, Biedermann B, Schadlich $\mathrm{H}$, Grosche J, Faude F, Wiedemann $P$, Allgaier C, Illes P, Burnstock $G$, Reichenbach A. 2000. P2X7 receptors in Muller glial cells from the human retina. J Neurosci 20:5965-5972.

Parkhurst CN, Gan WB. 2010. Microglia dynamics and function in the CNS. Curr Opin Neurobiol 20:595-600.

Pascual O, Ben AS, Rostaing P, Triller A, Bessis A. 2012. Microglia activation triggers astrocyte-mediated modulation of excitatory neurotransmission. Proc Natl Acad Sci U S A 109:E197-E205.

Pekny M, Pekna M, Messing A, Steinhauser C, Lee JM, Parpura V, Hol EM, Sofroniew MV, Verkhratsky A. 2016. Astrocytes: a central element in neurological diseases. Acta Neuropathol 131:323-345.

Pelegrin P, Surprenant A. 2006. Pannexin-1 mediates large pore formation and interleukin-1beta release by the ATP-gated $\mathrm{P} 2 \mathrm{X} 7$ receptor. EMBO J 25:5071-5082.

Perea G, Navarrete M, Araque A. 2009. Tripartite synapses: astrocytes process and control synaptic information. Trends Neurosci 32:421-431.

Pougnet JT, Toulme E, Martinez A, Choquet D, Hosy E, Boue-Grabot E. 2014. ATP P2X receptors downregulate AMPA receptor trafficking and postsynaptic efficacy in hippocampal neurons. Neuron 83:417-430.

Ransohoff RM, Perry VH. 2009. Microglial physiology: unique stimuli, specialized responses. Annu Rev Immunol 27:119-145.

Rodrigues RJ, Tome AR, Cunha RA. 2015. ATP as a multitarget danger signal in the brain. Front Neurosci 9:148. 
Santiago MF, Veliskova J, Patel NK, Lutz SE, Caille D, Charollais A, Meda P, Scemes E. 2011. Targeting pannexin1 improves seizure outcome. PLoS One 6:e25178.

Sawada K, Echigo N, Juge N, Miyaji T, Otsuka M, Omote H, Yamamoto A, Moriyama Y. 2008. Identification of a vesicular nucleotide transporter. Proc Natl Acad Sci U S A 105:5683-5686.

Shemer A, Erny D, Jung S, Prinz M. 2015. Microglia plasticity during health and disease: an immunological perspective. Trends Immunol 36 : 614-624.

Sierra A, Encinas JM, Deudero JJ, Chancey JH, Enikolopov G, Overstreet-Wadiche LS, Tsirka SE, Maletic-Savatic M. 2010. Microglia shape adult hippocampal neurogenesis through apoptosis-coupled phagocytosis. Cell Stem Cell 7:483-495.

Sierra A, Martin-Suarez S, Valcarcel-Martin R, Pascual-Brazo J, Aelvoet SA, Abiega O, Deudero JJ, Brewster AL, Bernales I, Anderson AE, Baekelandt V, Maletic-Savatic M, Encinas JM. 2015. Neuronal hyperactivity accelerates depletion of neural stem cells and impairs hippocampal neurogenesis. Cell Stem Cell 16:488-503.

Sim JA, Chaumont S, Jo J, Ulmann L, Young MT, Cho K, Buell G, North RA, Rassendren F. 2006. Altered hippocampal synaptic potentiation in P2X4 knockout mice. J Neurosci 26:9006-9009.

Solle M, Labasi J, Perregaux DG, Stam E, Petrushova N, Koller BH, Griffiths RJ, Gabel CA. 2001. Altered cytokine production in mice lacking P2X(7) receptors. J Biol Chem 276:125-132.

Steinhauser C, Boison D. 2012. Epilepsy: crucial role for astrocytes. Glia 60:1191.

Steinhauser C, Grunnet M, Carmignoto G. 2015. Crucial role of astrocytes in temporal lobe epilepsy. Neuroscience 323:157-169.

Taylor SR, Gonzalez-Begne M, Sojka DK, Richardson JC, Sheardown SA, Harrison SM, Pusey CD, Tam FW, Elliott Jl. 2009. Lymphocytes from P2X7-deficient mice exhibit enhanced P2X7 responses. J Leukoc Biol 85:978-986.

Tsuda M, Shigemoto-Mogami Y, Koizumi S, Mizokoshi A, Kohsaka S, Salter MW, Inoue K. 2003. P2X4 receptors induced in spinal microglia gate tactile allodynia after nerve injury. Nature 424:778-783.

Tsuda M, Beggs S, Salter MW, Inoue K. 2013. Microglia and intractable chronic pain. Glia 61:55-61.
Ulmann L, Hatcher JP, Hughes JP, Chaumont S, Green PJ, Conquet F, Buell GN, Reeve AJ, Chessell IP, Rassendren F. 2008. Upregulation of $\mathrm{P} 2 \mathrm{X} 4$ receptors in spinal microglia after peripheral nerve injury mediates BDNF release and neuropathic pain. J Neurosci 28:11263-11268.

Ulmann L, Hirbec H, Rassendren F. 2010. P2X4 receptors mediate PGE2 release by tissue-resident macrophages and initiate inflammatory pain. EMBO J 29:2290-2300.

Ulmann L, Levavasseur F, Avignone E, Peyroutou R, Hirbec H, Audinat E, Rassendren F. 2013. Involvement of P2X4 receptors in hippocampal microglial activation after status epilepticus. Glia 61:13061319.

Verkhratsky A, Krishtal OA, Burnstock G. 2009. Purinoceptors on neuroglia. Mol Neurobiol 39:190-208.

Vezzani A, Balosso S, Ravizza T. 2008. The role of cytokines in the pathophysiology of epilepsy. Brain Behav Immun 22:797-803.

Vezzani A, French J, Bartfai T, Baram TZ. 2011. The role of inflammation in epilepsy. Nat Rev Neurol 7:31-40.

Vianna EP, Ferreira AT, Dona F, Cavalheiro EA, da Silva Fernandes MJ. 2005. Modulation of seizures and synaptic plasticity by adenosinergic receptors in an experimental model of temporal lobe epilepsy induced by pilocarpine in rats. Epilepsia 46(Suppl 5):166-173.

von K€ugelgen I, Hoffmann K. 2015. Pharmacology and structure of P2Y receptors. Neuropharmacology [E-pub ahead of print] doi: 10.1016/ j.neuropharm.2015.10.030.

Wei YJ, Guo W, Sun FJ, Fu WL, Zheng DH, Chen X, Li S, Zang ZL, Zhang CQ, Liu SY, Yang H. 2015. Increased expression and cellular localization of P2X7R in cortical lesions of patients with focal cortical dysplasia. J Neuropathol Exp Neurol [E-pub ahead of print].

White TD. 1978. Release of ATP from a synaptosomal preparation by elevated extracellular K 1 and by veratridine. J Neurochem 30:329-336.

Wu LJ, Stevens B, Duan S, MacVicar BA. 2013. Microglia in neuronal circuits. Neural Plast 2013:586426.

Zhang Z, Chen G, Zhou W, Song A, Xu T, Luo Q, Wang W, Gu XS, Duan S. 2007. Regulated ATP release from astrocytes through lysosome exocytosis. Nat Cell Biol 9:945-953.

Zorec R, Araque A, Carmignoto G, Haydon PG, Verkhratsky A, Parpura V. 2012. Astroglial excitability and gliotransmission: an appraisal of $\mathrm{Ca} 21$ as a signalling route. ASN Neuro 4. 